\title{
C25 Steroid Epimers Produced by Penicillium janthinellum, a Fungus Isolated from Fruits Melia azedarach
}

\author{
Andrey M. do Rosário Marinho ${ }^{a}$, Edson Rodrigues-Filho $^{*, a}$, Antônio Gilberto Ferreira ${ }^{a}$ \\ and Lourivaldo S. Santos ${ }^{b}$ \\ ${ }^{a}$ Departamento de Química, Universidade Federal de São Carlos, CP 676, 13.565-905 \\ São Carlos - SP, Brazil \\ ${ }^{b}$ Departamento de Química, Universidade Federal do Pará, Av. Augusto Corrêa, 1 - 66075-970 \\ Belém - PA, Brazil
}

\begin{abstract}
O fungo Penicillium janthinellum, obtido de Melia azedarach, produziu ergosterol, ergosterol $5 \alpha, 8 \alpha$-peróxido e uma mistura de esteróides C25 epiméricos de ocorrência restrita na natureza. Os esteróides C25, denominados neociclocitrinóis, possuem o mesmo sistema tetracíclico de anéis presente no ciclocitrinol, o qual foi isolado do fungo Penicillium citrinum, associado a uma esponja, com o mesmo esqueleto biciclo[4:4:1] nos anéis $\mathrm{A} / \mathrm{B}$, mas com cadeias laterais diferentes. O $P$. janthinellum isolado de $M$. azedarach, foi cultivado sobre milho branco e os três esteróides foram isolados por vários procedimentos cromatográficos e identificados por cuidadosa análise dos dados de RMN, principalmente correlações ${ }^{1} \mathrm{H}-{ }^{13} \mathrm{C}$ em duas dimensões bem como COSY e TOCSY ${ }^{1} \mathrm{H}$ $-{ }^{1} \mathrm{H}$. A origem biossintética dos ciclocitrinóis é discutida.
\end{abstract}

A plant-derived fungus, Penicillium janthinellum, obtained from Melia azedarach, produced ergosterol and ergosterol $5 \alpha, 8 \alpha$-peroxide along with a mixture of rare $\mathrm{C} 25$ steroid epimers. The $\mathrm{C} 25$ steroids, named neocyclocitrinols, shows exactly the same tetracyclic ring system present in cyclocitrinol, which was isolated from a sponge-derived Penicillium citrinum, with the same bicyclo [4:4:1] skeleton at A/B rings, but showing different side chains. The P. janthinellum was cultivated over white corn and the three steroids were isolated by several silica gel based chromatographic procedures and identified by extensive NMR methods, mainly ${ }^{1} \mathrm{H}-{ }^{13} \mathrm{C}$ correlations and ${ }^{1} \mathrm{H}-{ }^{1} \mathrm{H}$ COSY and TOCSY. The biosynthetic origin of the cyclocitrinols is also discussed.

Keywords: endophytic fungi, Melia azedarach, Penicillium janthinellum, neocyclocitrinols

\section{Introduction}

Steroid and steroid derived secondary metabolites are frequently found in filamentous fungi. ${ }^{1}$ Ergosterol (1) is the precursor of many other microbial steroids. ${ }^{2}$ Most of the ergosterol metabolism begins with an oxidative process in double-bonds at C-5(6) and C-7(8) letting to ergosterol 5,8 -peroxide, ${ }^{3}$ being the endo regioisomer $(5 \alpha, 8 \alpha$ peroxide) (2) the most frequent, and then hydroxylated products at $\mathrm{A} / \mathrm{B} / \mathrm{C}$ rings are formed. ${ }^{4}$ In the present work we have found these sorts of compounds in our chemical studies of endophytic filamentous fungi associated with Meliaceae plants. We previously described the production of polyketides by a Penicillium janthinellum, isolated from fruits of Melia azedarach. ${ }^{5}$ Now we report the production of a pair of steroid epimers with a very unusual C25

\footnotetext{
* e-mail: edson@dq.ufscar.br
}

skeleton, in addition to the regular steroids ( $\mathbf{1}$ and $\mathbf{2}$ ), when the fungus was cultivated over white corn. These epimers, which are represented here by the structural formula $\mathbf{3}$, contains a rare bicyclo [4:4:1] system at rings $\mathrm{A} / \mathrm{B}$, as in cyclocitrinol (4) and isocyclocitrinol (5) obtained by Amagata et al. ${ }^{6}$ from $P$. citrinum, isolated from a marine sponge. ${ }^{6}$ Herein we present spectroscopic evidences, which further support the bicycle system of these compounds and firmly establish the side chain of the new steroid neocyclocitrinol (3). Biosynthetic considerations regard the origin of these steroids are also discussed.

\section{Results and Discussion}

The methanol extract obtained from a twenty-days old culture of $P$. janthinellum, was partitioned between methanol and hexane. The steroids $\mathbf{1}$ and $\mathbf{2}$ accumulated in the hexane phase and were isolated by silica gel open 
column chromatography and identified as ergosterol and ergosterol $5 \alpha, 8 \alpha$-peroxide respectively, by comparison of their ${ }^{1} \mathrm{H}$ and ${ }^{13} \mathrm{C}$ NMR spectra with those reported in the literature. ${ }^{7,8}$ The neocyclocitrinols (3) were obtained from the methanol phase. The hydroxyanthraquinones we reported before in another cultivation of the fungus, ${ }^{5}$ were also obtained from this methanol phase.

The compound $\mathbf{3}$ was analyzed by atmosphere pressure chemical ionization mass spectrometry (APCIMS) in positive ion mode. The full scan mass spectrum obtained showed a base peak at $m / z 401$, which was later identified as $[\mathrm{M}+\mathrm{H}]^{+}$, and minor ions at $m / z, 423\left([\mathrm{M}+\mathrm{Na}]^{+}\right)$and 442 $\left([\mathrm{M}+\mathrm{H}+\mathrm{AcN}]^{+}\right)$. The daughter ion scan, using $\mathrm{m} / \mathrm{z} 401$ as the precursor ion, which was accelerated at $30 \mathrm{eV}$ to collide with argon (Ar), produced an spectrum showing steroid profile, with clusters of intense peaks at lighter ions region $(\mathrm{m} / \mathrm{z}, 100-200)$ and low abundant ions at high masses. The later region shows ion fragments corresponding to three losses of water $(\mathrm{m} / \mathrm{z} 383,365$ and 347), suggesting a trihydroxylated steroid. These MS spectra, in conjunction with the interpretation of the NMR data discussed below, indicated the molecular formula $\mathrm{C}_{25} \mathrm{H}_{36} \mathrm{O}_{4}(400 \mathrm{Da})$ for compound $\mathbf{3}$.

The signals in ${ }^{1} \mathrm{H}$ and ${ }^{13} \mathrm{C}$ NMR spectra of compound 3 did not show pattern for common steroids, as did the MS data. A careful inspection on these NMR spectra indicated that most of the signals were duplicated in an intensity ratio of 1:1. This was suggestive for the presence of two epimeric compounds. The ${ }^{1} \mathrm{H}$ NMR spectrum of $\mathbf{3}$ showed only one signal for methyl group $\left(\delta 0.55, \mathrm{~s}, \mathrm{CH}_{3}-18\right)$ attached to a quaternary $\mathrm{sp}^{3}$ hybrized carbon. Following the ${ }^{1} \mathrm{H}-{ }^{13} \mathrm{C}$ HMBC correlations of this methyl group, it was possible to find the signals of $\mathrm{C}-17(\delta$ 61.04), $\mathrm{C}-14(\delta$ 56.53), $\mathrm{C}-13(\delta 48.90)$ and $\mathrm{C}-12(\delta 39.04)$ in the ${ }^{13} \mathrm{C}$ spectrum. These HMBC correlations (see Table 1) along with careful analysis of the ${ }^{1} \mathrm{H}-{ }^{1} \mathrm{H}$ COSY spectrum (Figure 1a), established the bicyclo [4:3:0], frequently found in rings C/D of steroids. ${ }^{9}$ The $\mathrm{H}-9(\delta 2.80$, dd $J 5.7$ and $12 \mathrm{~Hz})$ and $\mathrm{H}-14(\delta 2.21$, ddd $J 1.5,7.8$ and $9.2 \mathrm{~Hz}$ ) are correlated (HMBC) with two and one carbon-carbon double bond, respectively. These two double-bonds are therefore part of rings $\mathrm{A} / \mathrm{B}$. The absence of an additional methyl group $\left(\mathrm{CH}_{3}-\right.$ $19)$ in this part of the molecule indicated that compound $\mathbf{3}$ is not a regular steroid.

A literature search covering the recent publications on fungi steroid resulted in one hit showing good agreement with the spectroscopic data of compound $\mathbf{3}$. The steroid cyclocitrinol (4) was obtained from a sponge-derived $P$. citrinum and had its structure elegantly elucidated by NMR spectroscopic data, mainly ${ }^{1} \mathrm{H}-{ }^{1} \mathrm{H}$ COSY and ${ }^{1} \mathrm{H}-{ }^{13} \mathrm{C}$ $\mathrm{HMBC}$, and single crystal $\mathrm{X}$-ray diffraction analysis. ${ }^{6}$ The NMR data of $\mathbf{4}$, measured in chloroform- $d$ solution, are almost identical with those we obtained for $\mathbf{3}$ (Table 1), mainly with regard the tetracyclic ring system. Slight differences in chemical shift of ${ }^{1} \mathrm{H}$ and ${ }^{13} \mathrm{C}$ were detected, since our data were obtained in methanol- $d_{4}$, a polar-protic solvent. Besides the correlations of $\mathrm{H}-9$ and $\mathrm{H}-14$ with the double-bond carbons at C-1(10) $(\delta 123.30 / 123.28, \mathrm{C}-1$ and 147.70, C-10) and C-7(8) $(\delta 125.53 / 125.50, \mathrm{C}-7$ and $160.39 / 160.30$, C-8) respectively, the correlation of the carbonyl carbon at $\delta 207.84$ with two pair of methylenic hydrogens $(\delta 1.62-1.50, \mathrm{H}-4 \mathrm{a}$ and $2.74, \mathrm{H}-4 \mathrm{~b} ; \delta 2.57-2.47$, H-19) were important guide to establish the bicyclo system at $\mathrm{A} / \mathrm{B}$ rings. This partial structure was also confirmed by
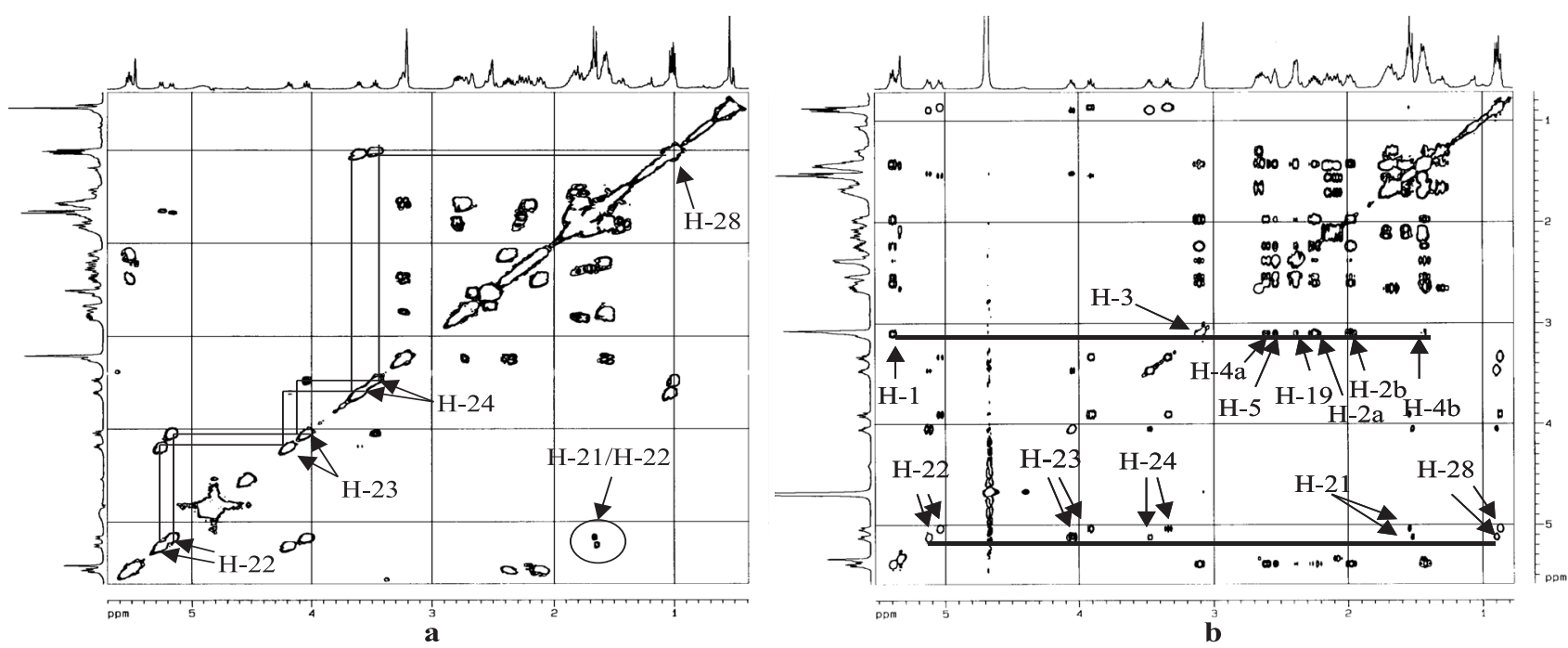

Figure 1. ${ }^{1} \mathrm{H}-{ }^{1} \mathrm{H} 2 \mathrm{D}$ spectra obtained for neocyclocitrinol (3) in $\mathrm{CD}_{3} \mathrm{OD}$. a: COSY spectrum produced after transformation of $253 \mathrm{FIDs}$, each of them composed of 16 transients, with an interpulse delay of $1.5 \mathrm{~s}$. b: TOCSY spectrum obtained after transformation of 400 FIDs (16 transients each), with an interpulse delay of $1.2 \mathrm{~s}$ and $80 \mathrm{~ms}$ as mixing time. 
Table 1. ${ }^{1} \mathrm{H}$ and ${ }^{13} \mathrm{C}$ NMR data obtained for neocyclocitrinol (3)

\begin{tabular}{|c|c|c|c|}
\hline & $\delta{ }^{13} \mathrm{C}$ & $\delta{ }^{1} \mathrm{H}(\mathrm{m}, J)$ & ${ }^{1} \mathrm{H} \rightarrow{ }^{13} \mathrm{C}$ Correlation \\
\hline 1 & $123.30 / 123.28$ & $5.51(\mathrm{dd}, 6.8,7.2)$ & $\mathrm{C}-2, \mathrm{C}-3, \mathrm{C}-9, \mathrm{C}-19$ \\
\hline $2 \mathrm{a}$ & 36.99 & $2.11(\mathrm{ddd}, 2.8,7.2,13.8)$ & $\mathrm{C}-1, \mathrm{C}-3, \mathrm{C}-4, \mathrm{C}-10$ \\
\hline $2 b$ & - & $2.38(\mathrm{ddd}, 6.8,11.2,13.8)$ & $\mathrm{C}-1, \mathrm{C}-3, \mathrm{C}-4, \mathrm{C}-10$ \\
\hline 3 & 65.41 & $3.24(\mathrm{~m})$ & n.d. \\
\hline $4 \mathrm{a}$ & 42.30 & $1.62-1.50(\mathrm{~m})$ & $\mathrm{C}-3, \mathrm{C}-6$ \\
\hline $4 \mathrm{~b}$ & - & 2.74 (br d, 13.4) & $\mathrm{C}-2, \mathrm{C}-3$ \\
\hline 5 & 50.10 & $2.69-2.63(\mathrm{~m})$ & C-3, C-4, C-19 \\
\hline 6 & 207.84 & - & - \\
\hline 7 & $125.53 / 125.50$ & 5.47 (br s) & C-5, C-8, C-14 \\
\hline 8 & $160.39 / 160.30$ & - & - \\
\hline 9 & 55.69 & $2.80(\mathrm{dd}, 5.7,12.0)$ & C-1, C-7, C-8, C-10, C-11, C-19 \\
\hline 10 & 147.70 & - & - \\
\hline $11 \mathrm{a}$ & $29.10 / 29.06$ & $1.86-1.75(\mathrm{~m})$ & n.a. \\
\hline $11 \mathrm{~b}$ & - & $1.62-1.50(\mathrm{~m})$ & C- 8 \\
\hline $12 \mathrm{a}$ & 39.04 & $1.80-1.73(\mathrm{~m})$ & n.a. \\
\hline $12 b$ & - & $1.46(\mathrm{dd}, 4.8,11.6)$ & $\mathrm{C}-11, \mathrm{C}-13, \mathrm{C}-17, \mathrm{C}-18$ \\
\hline 13 & 48.90 & - & - \\
\hline 14 & 56.53 & $2.21(\mathrm{ddd}, 1.5,7.8,9.2)$ & $\mathrm{C}-7, \mathrm{C}-8, \mathrm{C} 13, \mathrm{C}-15, \mathrm{C}-18$ \\
\hline $15 \mathrm{a}$ & 24.02 & $1.62-1.50(\mathrm{~m})$ & C-8, C-13, C-17 \\
\hline $15 b$ & - & $1.62-1.50(\mathrm{~m})$ & C-8, C-13, C-17 \\
\hline $16 \mathrm{a}$ & 25.43 & $1.80-1.70(\mathrm{~m})$ & n.a. \\
\hline $16 \mathrm{~b}$ & - & $1.70-1.60(\mathrm{~m})$ & n.a. \\
\hline 17 & 61.04 & $2.29(\mathrm{ddd}, 1.7,8.6,9.7)$ & $\mathrm{C}-12, \mathrm{C}-13, \mathrm{C}-16, \mathrm{C}-18, \mathrm{C}-20, \mathrm{C}-22$ \\
\hline 18 & $14.21 / 14.15$ & $0.55(\mathrm{~s})$ & C- $12, \mathrm{C}-13, \mathrm{C}-14, \mathrm{C}-17$ \\
\hline $19 \mathrm{a}$ & 28.68 & $2.57-2.47(\mathrm{~m})$ & C-1, C-4, C-5, C-6, C-9, C-10 \\
\hline $19 b$ & - & $2.57-2.47(\mathrm{~m})$ & C-1, C-4, C-5, C-6, C-9, C-10 \\
\hline 20 & $139.97 / 139.43$ & - & - \\
\hline 21 & $18.28 / 18.17$ & $1.67(\mathrm{~d}, 1) / 1.65(\mathrm{~d}, 1)$ & C-17, C-20, C-22 \\
\hline 22 & $128.02 / 127.58$ & $5.26($ br d, 8.4)/5.17 (br d, 9.0) & $\mathrm{C}-17, \mathrm{C}-21, \mathrm{C}-24$ \\
\hline 23 & $74.15 / 73.39$ & $4.18(\mathrm{dd}, 6.3,9.0) / 4.04(\mathrm{dd}, 6.8,8.4)$ & $\mathrm{C}-20, \mathrm{C}-22, \mathrm{C}-24, \mathrm{C}-28$ \\
\hline 24 & $72.54 / 71.83$ & $3.60(\mathrm{dq}, 6.3,7.3) / 3.47(\mathrm{qp}, 6.8)$ & C- 23 \\
\hline 28 & $19.27 / 18.48$ & $1.00(\mathrm{~d}, 7.3) / 1.02(\mathrm{~d}, 6.8)$ & $\mathrm{C}-23$ \\
\hline
\end{tabular}

analysis of the ${ }^{1} \mathrm{H}-{ }^{1} \mathrm{H}$ COSY and TOCSY experiments (Figures 1a and 1b, respectively). Thus, the vinillyc hydrogen $\mathrm{H}-1$ is strongly coupled with the methylenic hydrogens $\mathrm{H}-2 \mathrm{a}(\delta 2.11$, ddd $J 2.8,7.2$ and $13.8 \mathrm{~Hz})$ and $\mathrm{H}-$ $2 \mathrm{~b}(\delta 2.38$, ddd $J 6.8,11.2$ and $13.8 \mathrm{~Hz})$ (Figure 1a). The TOCSY spectra shows correlations between the hydrogens forming the spin-spin net H-1, H-2a, H-2b, H-3, H-4a, H$4 b, \mathrm{H}-5$ and H-19 (see Figure 1b). The presence of a doublebound in such a position in the bicycle system, which means a bridge-head position, could lead to an unstable molecule. But, in this case, geometry optimization by computational software (HyperChem) ${ }^{10}$ showed that the four atoms directly attached to the $\mathrm{sp}^{2}$ carbons $\mathrm{C}-1$ ( $\mathrm{H}-1$, C-2) and C-10 (C-9 and C-19) are located in the same plane. An approximated shape, resulted from these calculations, is given in Figure 2.

The NMR data indicated that the constitutional steroids isomers $\mathbf{3}$ and $\mathbf{4}$ differ only by their side chain at C-17. The signal for H-17 ( $\delta 2.29)$ in the HMBC spectrum of $\mathbf{3}$ is correlated with two $\mathrm{sp}^{2}$ carbons, suggesting the presence of a carbon-carbon double bound at C-20(22) $(\delta$ $139.97 / 139.43$, C-20; 128.02/127.58, C-22). This is in

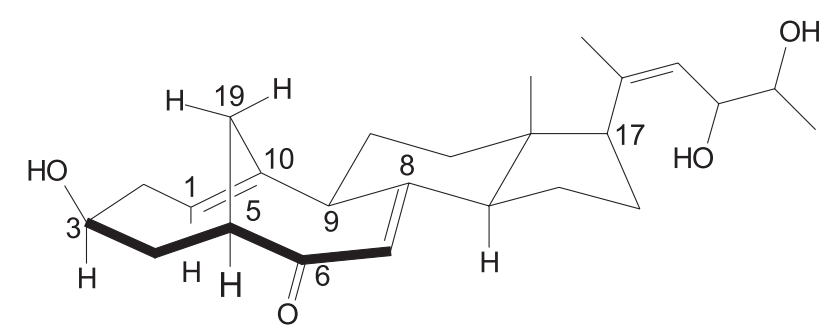

Figure 2. Reproduction of an approximately 3D view of the structure of neocyclocitrinol, obtained after geometry optimization by computational program.

agreement with the deshielding effect $(\Delta \delta+6.34)$ over $\mathrm{C}-17(\delta$ 61.04) in $\mathbf{3}$ when compared with 4 . The HMBC correlations of $\mathrm{CH}_{3}-21(\delta 1.67 / 1.65, \mathrm{~d} J 1.0 \mathrm{~Hz})$ with C-17, $\mathrm{C}-20$ and C-22, along with the other correlations reported in Table 1, firmly indicated that steroid $\mathbf{3}$ contains a different side chain. The COSY spectrum (Figure 1a) shows correlations for H-22 $(\delta 5.26 / 5.17)$ with a carbinolic hydrogen $(\delta 4.18 / 4.04, \mathrm{H}-23)$, which is also coupled with another carbinolic hydrogen ( $\delta 3.60 / 3.47, \mathrm{H}-24)$. A methyl group $\left(\delta 1.02 / 1.00, \mathrm{CH}_{3}-28\right)$ is coupled with $\mathrm{H}-24$. These spin-spin connections were confirmed by the TOCSY experiment (Figure 1b). The duplication of the signals in 
the NMR spectra of $\mathbf{3}$ was more drastic for the side chain atoms, indicating that the epimerized center is located at C-23 or C-24, the only stereocenters at this part of the molecule. It was not found any HPLC condition to separate these epimers in preparative scale. Therefore the physical data of isomers 23,24-erythro and 23,24-threo were not individually ascribed.

The biosynthetic origin of these compounds (3-5) is not clear. Cyclocitrinol (4) was first isolated from a terrestrial $P$. citrinum and reported as a new sesterterpene. ${ }^{11}$ When it was re-isolated, along with isocyclocitrinol (5), from a Penicillium living in a marine substrate, its structure was revised on the basis of X-ray crystallography studies and an steroidal skeleton was suggested. ${ }^{6}$ Based on the cooccurrence of steroids $\mathbf{1}$ and $\mathbf{2}$ with $\mathbf{3}$, we suggested a chemically plausible route to the biclyclic system in the cyclocitrinols (3-5) (Scheme 1). Assuming the participation of enzymes able to make C-19 in ergosterol (1) a good electrophilic center, the electron in orbital $p$ at C-5 can act as a nucleophile, forming a C-5 - C-19 bond. This process can be favored by a nucleophilic oxidation at C-6 in 1a to produce the intermediate $\mathbf{1 b}$. The cyclopropane ring in $\mathbf{1 b}$ can be opened by deprotonation at $\mathrm{C}-1$, with the help of the carbonyl group at C-6, producing the cyclocitrinols 3-5.

The side chain of these steroids can also originate from ergosterol (1) (Scheme 1). Thus, oxidations at C-22, C-23 and $\mathrm{C}-25$ of $\mathbf{1}$ produce the intermediate $\mathbf{1 c}$, which is very suitable to eliminate acetone and produce $1 \mathbf{d}$. The intermediate $\mathbf{1 d}$ has the carbon skeleton of the steroids $\mathbf{3}$ 5. Further oxidations and rearrangement would lead to the cyclocitrinols.
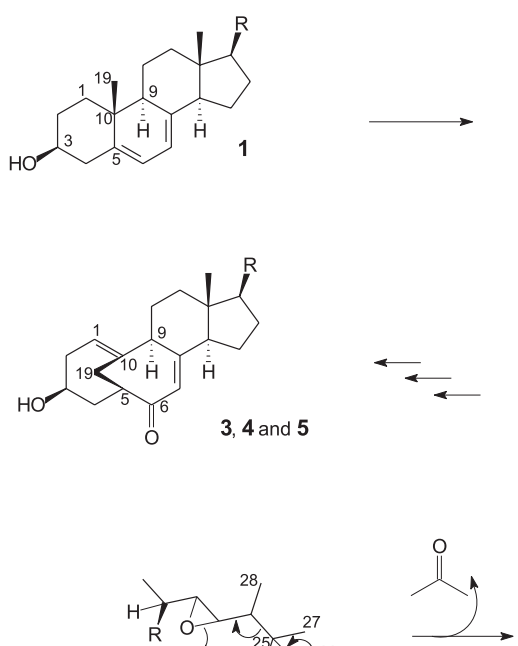

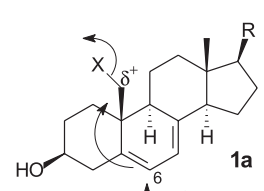

$\left[\mathrm{O}^{-}\right]$
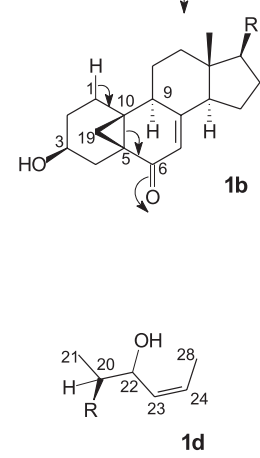

Scheme 1. Suggested biogenetic route to the bicyclo [4:4:1] ring system and the side chain of the unusual C25 steroids cyclocitrinols 3-5.
If ergosterol (1) is confirmed as the precursor of these steroids, the enzymes involved in those process (Scheme 1) must be investigated, since conversion of steroids by living microbes or pure enzymes is nowadays a good tool for pharmaceutical industries. ${ }^{12}$ Isocyclocitrinol (5) and its 22-acetyl derivative were inactive against human tumor cell lines and some bacterias. ${ }^{6}$ None of these cyclocitrinols 3-5 were tested in any other bioassay. These compounds deserve careful attention of researches, since they are very unusual steroidal compounds.
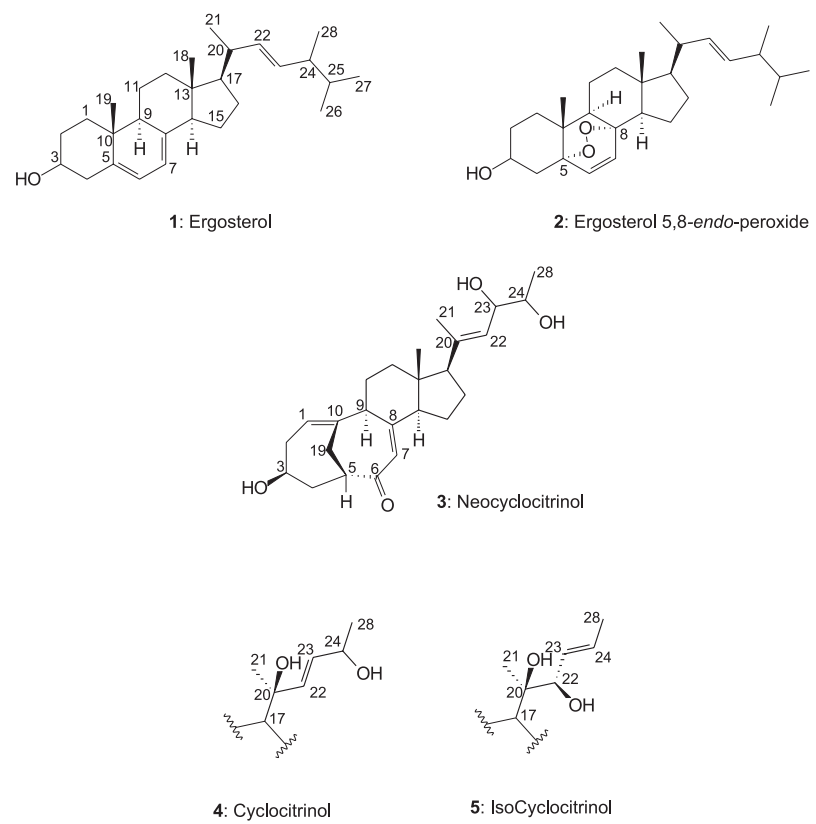

\section{Experimental}

\section{General procedures}

Optical rotations were measured on a PERKIN ELMER 241 polarimeter. UV spectra were obtained in methanol solution on a HEWLETT PACKARD 8452-A spectrophotometer, and IR spectra were measured with a BOMEN MB-102 spectrophotometer in KBr pellets. Lowresolution APCIMS data were acquired in positive ion mode, using a MICROMASS QUATTRO-LC instrument equipped with an API “'Z-spray” ion source. ${ }^{1} \mathrm{H}$ and ${ }^{13} \mathrm{C}$ NMR experiments were recorded on a BRUKER DRX-400 spectrometer with $\mathrm{CD}_{3} \mathrm{OD}$ as the solvent and TMS as the internal standard.

\section{Plant material and microorganism}

Details of plant material collection and fungus isolation were given in previous publications. ${ }^{5,13}$ 
White corn culture of P. janthinellum and isolation of the steroids

Large scale cultivation of the fungus on white corn was conducted exactly the same way described before. ${ }^{5}$ But, this time the $\mathrm{MeOH}$ added to stop the fungus growth was filtered under gravity, concentrated to $2.0 \mathrm{~L}$ and partitioned with $n-\mathrm{C}_{6} \mathrm{H}_{14}(3 \times 500 \mathrm{~mL})$. After evaporated under reduced pressure each phase were subjected to a low-pressure silica gel $\mathrm{CC}$ eluted with $n-\mathrm{C}_{6} \mathrm{H}_{14}$, EtOAc and $\mathrm{MeOH}$ gradient. The $n-\mathrm{C}_{6} \mathrm{H}_{14}$ extract produced the steroids $\mathbf{1}(85 \mathrm{mg})$ and $\mathbf{2}(29 \mathrm{mg})$ after repeatedly chromatography on silica gel CC $\left[n-\mathrm{C}_{6} \mathrm{H}_{14}\right.$ :EtOAc:MeOH (80:18:02), isocratic] and crystallization from $\mathrm{MeOH}$. The $\mathrm{MeOH}$ phase of the initial partitioning was concentrated to dryness and subjected to a low pressure fast chromatography eluted with $\mathrm{CH}_{2} \mathrm{Cl}_{2}$ (100\%), $\mathrm{CH}_{2} \mathrm{Cl}_{2}: \mathrm{MeOH}(9: 1)$ and $\mathrm{MeOH}(100 \%)$. The steroid 3 $(8.7 \mathrm{mg})$ was purified from the second fraction by flash chromatography on silica gel CC $\left[n-\mathrm{C}_{6} \mathrm{H}_{14}: \mathrm{CHCl}_{3}: \mathrm{EtOH}\right.$ (60:35:05), isocratic].

Neocyclocitrinols (3)

White amorphous powder; $[\alpha]_{\mathrm{D}}{ }^{25}+70.1^{\circ}(\mathrm{MeOH}, c$ $0.001) ; \mathrm{UV} \lambda_{\text {max }} / \mathrm{nm}\left(\mathrm{CH}_{2} \mathrm{Cl}_{2}\right): 265$; IR $(\mathrm{KBr}) v_{\max } / \mathrm{cm}^{-1}$ : 3414, 2921, 1669, 1639, 1635; ${ }^{1} \mathrm{H}$ NMR (400 MHz, $\left.\mathrm{CD}_{3} \mathrm{OD}\right)$ : see Table $1 ;{ }^{13} \mathrm{C}$ NMR (100 MHz, CD 3 OD): see Table 1; APCIMS (full scan, pos. ion mode): $m / z$ (rel. int.): $442[\mathrm{M}+\mathrm{H}+\mathrm{AcN}]^{+}(29), 423[\mathrm{M}+\mathrm{Na}]^{+}(6), 401[\mathrm{M}+\mathrm{H}]^{+}$ (100), $383\left[\mathrm{M}+\mathrm{H}-\mathrm{H}_{2} \mathrm{O}\right]^{+}$(29); APCIMS (daughter ion scan, $30 \mathrm{eV}): 401[\mathrm{M}+\mathrm{H}]^{+}(61), 383$ (10), 365 (7), $355(8), 347$ (7), 339 (12), 329 (13), 279 (21), 267 (22), 237 (24), 223 (14), 209 (23), 187 (64), 173 (83), 159 (53), 147 (62), 145 (100), 133 (58), 121 (48), 119 (49), 107 (33).

\section{Acknowledgements}

The authors are grateful to Fundação de Amparo à Pesquisa do Estado de São Paulo (FAPESP), Conselho
Nacional de Desenvolvimento Científico e Tecnológico (CNPq) and Fundação Coordenação de Aperfeiçoamento de Pessoal de Ensino Superior (CAPES) for financial support and research fellowships

\section{References}

1. Turner, W.B; Aldridge, D.C.; Fungal Metabolites II, Academic Press: London, 1983, p. 225.

2. Hirotani, M.; Kaneko, A.; Asada, Y.; Yoshikawa, T.; Tetrahedron Lett. 2000, 41, 6101.

3. Sgarbi, D.B.; da Silva, A.J.R; Carlos, I.Z.; Silva, C.L.; Angluster, J.; Alviano, C.S.; Mycopathologia 1997, 139, 9.

4. Yue, J.M.; Chen, S.N.; Lin, Z.W.; Sun, H.D.; Phtochemistry 2001, 56, 801.

5. Marinho, A.M.R.; Rodrigues-Fo, E; Moitinho, M.L.R; Santos, L.S.; J. Braz. Chem. Soc. 2005, 2, 280.

6. Amagata, T.; Amagata, A.; Tenney, K.; Valeriote, F.A.; Lobkovsky, E.; Clardy, J.; Crews, P.; Org. Lett. 2003, 5, 4393.

7. Reich, H.J.; Jautelat, M.; Messe, M.T.; Weigert, F.J.; Roberts, J.D.; J. Am. Chem. Soc. 1969, 91, 7445.

8. Bok, J.W.; Lermer, L.; Chilton, J.; Kliingeman, H.G.; Towers, G.H.N.; Phytochemistry 1999, 51, 891.

9. Thummel, C.S.; Chory, J.; Genes \& Dev. 2002, 16, 3113.

10. Froimowitz M.; Biotechniques 1993, 14, 1010.

11. Kozlovsky, A.G.; Zhelifonova, V.P.; Ozerskaya, S.M.; Vinokurova, N.G.; Adanin, V.M.; Grafe, U.; Pharmazie 2000, $55,470$.

12. Fernandes, P.; Cruz, A.; Angelova, B.; Pinheiro, H.M.; Cabral, J.M.S.; Enzyme Microb. Technol. 2003, 32, 688.

13. Santos, R.M.G; Rodrigues-Fo, E; Rocha, W.C.; Teixeira, M.F.S.; World J. Microbiol. Biotechnol. 2003, 19, 767.

Received: August 2, 2004

Published on the web: August 30, 2005

FAPESP helped in meeting the publication costs of this article. 